\title{
Peningkatan Hasil Belajar Peserta Didik Tema Ekosistem Melalui Media Power Point Di Kelas V
}

\section{Regi Gunawan}

SD Negeri Kutasari 05

regigunawan51@gmail.com

\section{Article History}

accepted 01/11/2020

approved 08/11/2020

published 15/11/2020

\begin{abstract}
In general, the purpose of this research is to improve the learning of ecosystem themes of students in grade $V$ of SD Negeri kutasari 05. while the special goal is to improve the learning results of the Ecosystem Theme using power point media. Class Action Research (PTK) conducted in three cycles, each cycle consists of planning, implementation, observation, and reflection stages. The subject of this study is students of Grade V SD Kutasari 05 Cipari District Cilacap District in the 2020/2021 school year which numbered 16 students. Data collection techniques using using tests. This research shows that the use of power point media can improve the learning results in thematic learning of students in Grade V SD Kutasari 05 years of study year 2020/2021 as evidenced by the percentage of completeness of learning results in cycle I by $72.36 \%$, cycle II by $90.1 \%$, and cycle III reaching $100 \%$.
\end{abstract}

Keywords: Study results, Power point, Students

\section{Abstrak}

Secara umum tujuan dari penelitian ini adalah untuk meningkatkan pembelajaran Tema Ekosistem siswa kelas V SD Negeri kutasari 05. sedangkan tujuan khusus adalah meningkatkan hasil belajar Tema Ekosistem menggunakan media Power point. Penelitian Tindakan kelas ( PTK ) yang dilaksanakan dalam tiga siklus, setiap siklus terdiri dari tahap perencanaan, pelaksanaan, observasi, dan refleksi. Subjek penelitian ini adalah siswa kelas $\mathrm{V}$ SD Negeri Kutasari 05 Kecamatan Cipari Kabupaten Cilacap tahun pelajaran 2020/2021 yang berjumlah 16 siswa. Teknik pengumpulan data menggunakan menggunakan tes. Penelitian ini menunjukkan bahwa penggunaan media power point dapat meningkatkan hasil belajar pada pembelajaran tematik siswa kelas V SD Negeri Kutasari 05 tahun pelajaran 2020/2021 yang dibuktikan dengan presentase ketuntasan hasil belajar pada siklus I sebesar $72,36 \%$, siklus II sebesar 90,1\%, dan siklus III mencapai 100\%.

Kata kunci: Hasil Belajar, Power Point, Siswa

Social, Humanities, and Education Studies (SHEs): Conference Series https://jurnal.uns.ac.id/shes 


\section{PENDAHULUAN}

Berdasarkan data nilai ulangan harian kelas V SDN Kutasari 05 Cipari. diperoleh informasi bahwa hasil belajar siswa pada Tema Ekosistem masih relatif rendah. Hal ini ditunjukkan dari perolehan hasil belajar siswa yang meliputi hasil ulangan harian Tema Ekosistem, menunjukkan bahwa nilai rata-rata kelas yaitu 60 dari nilai KKM 70 dengan jumlah keseluruhan 16 siswa. Berdasarkan hasil kajian pustaka menemukan bahwa model pembelpelajaran Power point berpotensi untuk meningkatkan hasil belajar siswa. Dengan menerapkan model Power point pada Tema 5 Sub tema 1 pembelajaran 1 SD Negeri Kutasari 05 maka siswa tidak akan mudah merasa bosan selama kegiatan belajar mengajar berlangsung hingga materi yang diajarkan guru dapat tersampaikan dengan baik dan hasilnya dapat terlihat dari hasil belajar yang meningkat. Dengan penerapan rumusan tersebut siswa juga dituntut untuk aktif dalam kegiatan pembelpelajaran sehingga siswa akan menemukan sendiri konsep yang akan ia pelajari.

Berdasarkan identifikasi dan analisis masalah di atas, maka masalah dalam penelitian tindakan kelas ini di rumuskan sebagai berikut, Bagaimana penerapan Power point dalam Tema Ekosistem pada siswa kelas V SD Negeri kutasari 05, Apakah model Power point dapat meningkatan pembelajan Tema Ekosistem pada siswa kelas V SD Negeri kutasari 05.

Daryanto (2010: 67-68), powerpoint adalah salah satu program aplikasi untuk media presentasi. Yang membedakan antara media presentasi dengan media pada umumnya adalah pada media presentasi pesan atau materi yang akan disampaikan dikemas dalam sebuah program komputer dan disajikan melalui perangkat presentasi berupa proyektor untuk menampilkan pesan atau materi berupa teks, gambar, animasi, maupun video yang dikombinasi secara utuh. Apabila dalam tampilan powerpoint akan ditambahkan efek suara, maka diperlukan alat tambahan berupa speaker. Jadi, media powerpoint adalah salah satu sarana penyampaian informasi dalam proses pembelajaran berupa program komputer yang dirancang untuk menyampaikan materi berupa slide-slide dengan berbagai kemampuan pengolahan teks, warna, suara, video, gambar, serta animasi-animasi yang bisa diolah sendiri sesuai kreativitas penggunanya, yang kesemuanya dapat ditampilkan melalui perangkat presentasi berupa proyektor dan speaker.

Menurut Oemar Hamalik (2001: 16), mengemukakan bahwa pemakaian media pengajaran dalam proses belajar mengajar dapat membangkitkan motivasi dan rangsangan kegiatan belajar, dan bahkan membawa pengaruhpengaruh psikologis terhadap siswa. Penggunaan media pengajaran pada tahap orientasi pengajaran akan sangat membantu keefektifan proses pembelajaran dan penyampaian pesan isi pelajaran. Di samping itu, media pembelajaran juga dapat membantu peserta didik meningkatkan pemahaman, menyajikan data dengan menarik dan terpercaya, memudahkan penafsiran data, dan memadatkan informasi. Adapun media pembelajaran yang peneliti pilih adalah media powerpoint.

Diharapkan setelah tindakan pembelajaran dilakukan, terdapat peningkatan kreativitas siswa dan nilai rata-rata ulangan harian Tema Ekosistem meningkat menjadi sekurang- kurangnya mencapai 70 . Secara umum tujuan dari penelitian ini adalah untuk meningkatkan pembelajaran Tema Ekosistem pada siswa kelas V SD Negeri kutasari 05. sedangkan tujuan khusus penelitian ini adalah untuk mendeskripsikan penerapan media Power point dalam pembelajaran Tema Ekosistem pada siswa dan meningkatkan hasil belajar Tema Ekosistem pada siswa kelas V SD Negeri kutasari 05 menggunakan media Power point 


\section{METODE}

Penelitian ini merupakan Penelitian Tindakan Kelas (PTK) yang dilaksanakan dalam tiga siklus. Setiap siklus terdiri dari tahap perencanaan, pelaksanaan, observasi, dan refleksi. Subjek penelitian ini adalah siswa kelas V SD Negeri Kutasari 05 tahun pelajaran 2020/2021 yang berjumlah 16 siswa. Data yang dianalisis berupa data kualitatif yaitu penggunaan media power point dan data kuantitatif yaitu hasil belajar siswa. Teknik pengumpulan data menggunakan tes dan observasi.

\section{HASIL DAN PEMBAHASAN}

Berdasarkan analisis hasil penelitian yang telah diuraikan, berikut penulis sampaikan pembahasan pada penelitian ini. Hasil penelitian menunjukkan peningkatan yang dilakukan oleh guru. Terlihat pada tabel berikut.

Tabel 1. Rekapitulasi Pra Siklus, Siklus I, Siklus II, Siklus III

\begin{tabular}{llcc}
\hline Siklus & Kategori & Jumlah & Presentase \\
\hline Pra Siklus & Tuntas & 6 & $38 \%$ \\
& Tidak Tuntas & 10 & $62 \%$ \\
Siklus I & Tuntas & 9 & $56 \%$ \\
& Tidak Tuntas & 7 & $44 \%$ \\
Siklus II & Tuntas & 14 & $88 \%$ \\
& Tidak Tuntas & 2 & $22 \%$ \\
Siklus III & Tuntas & 16 & $100 \%$ \\
& Tidak Tuntas & 0 & $0 \%$ \\
\hline
\end{tabular}

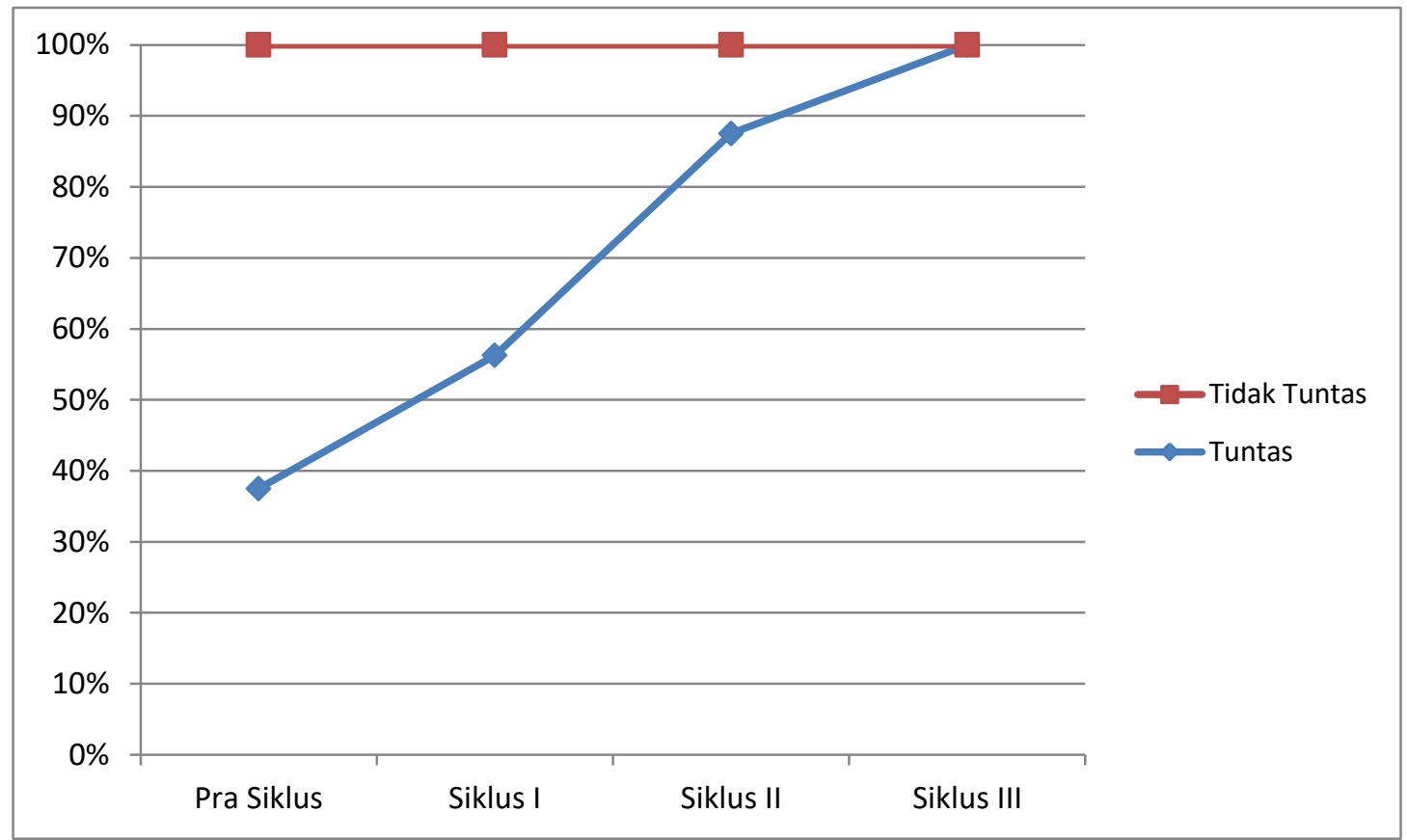

Gambar 1. Rekapitulasi Pra Siklus, Siklus I, Siklus II, Siklus III 
SHEs: Conference Series 3 (3) (2020) $309-313$

Tabel dan gambar di atas menunjukkan adanya peningkatan nilai rata- rata dan ketuntasan belajar yang diperoleh siswa. Hasil belajar siswa diukur dengan teknik tes menggunakan instrumen evaluasi berupa soal pilihan ganda, isian singkat, dan uraian. Soal dibuat menggunakan lembar evaluasi secara luring. Pengumpulan data hasil belajar peserta didik dilakukan setiap selesai pembelajaran. Instrumen soal sudah mengacu pada Higher Order Thinking Skills (HOTS), yaitu mengukur aspek kognitif yang terdiri dari menganalisis (C4), mengevaluasi (C5), dan mencipta (C6).

Penggunaan media power point dalam pembelajaran tematik kelas $\mathrm{V}$ di SD Negeri Kutasari 05 dapat meningkatkan hasil belajar siswa secara signifikan. Pada hasil penilaian kondisi awal terdapat 6 dari 16 siswa yang mencapai KKM atau $38 \%$. Setelah dilakukan tindakan pada siklus I terdapat peningkatan jumlah siswa tuntas belajar, yaitu dari 9 siswa atau $56 \%$. Pada siklus II juga terdapat peningkatan jumlah siswa tuntas belajar yaitu 14 dari 16 siswa atau $88 \%$. Pada siklus III hasil belajar siswa juga terus meningkat dan mencapai $100 \%$ siswa tuntas dengan KKM sekolah 70 sehingga pelaksanaan penelitian tindakan kelas dapat dihentikan.

Peningkatan hasil belajar tersebut sesuai dengan yang diungkapkan oleh Oemar Hamalik (2001: 16), mengemukakan bahwa pemakaian media pengajaran dalam proses belajar mengajar dapat membangkitkan motivasi dan rangsangan kegiatan belajar, dan bahkan membawa pengaruh-pengaruh psikologis terhadap siswa. Penggunaan media pengajaran pada tahap orientasi pengajaran akan sangat membantu keefektifan proses pembelajaran dan penyampaian pesan isi pelajaran. Di samping itu, media pembelajaran juga dapat membantu peserta didik meningkatkan pemahaman, menyajikan data dengan menarik dan terpercaya, memudahkan penafsiran data, dan memadatkan informasi. Adapun media pembelajaran yang peneliti pilih adalah media powerpoint

\section{SIMPULAN}

Berdasarkan penelitian tindakan kelas yang dilakukan di SD Negeri Kutasari 05 Kecamatan Cipari Kabupaten Cilacap dapat disimpulkan bahwa penggunaan media Power Point dapat meningkatkan hasil belajar Tema Ekosistem Sub tema Komponen Ekosistem. Peningkatan hasil belajar ditandai dengan nilai siswa yang mencapai KKM sebesar 70, yakni pada pra siklus nilai dari 16 siswa diketahui hanya $6(38 \%)$ siswa yang tuntas. Kemudian pada siklus I meningkat menjadi $9(56 \%)$ siswa yang tuntas. Pada siklus II mengalami peningkatan yaitu sebanyak 14 (88\%) siswa tuntas serta adanya peningkatan Kriteria Ketuntasan Klasikal pada siklus I sebesar $38,7 \%$ dan siklus II sebesar $87 \%$. Dan pada siklus III hasil belajar siswa mengalami peningkatan dari 27 (87\%) siswa yang tuntas menjadi $31(100 \%)$ siswa yang tuntas. 


\section{DAFTAR PUSTAKA}

Achmadi, Abu dan Cholid Narbuko, 2010. Metode Penelitian. Jakarta: Bumi Aksara.

Arikunto, S. (2013). Prosedur Penelitian: Suatu Pendekatan Praktik. Jakarta: Rineka Cipta.

Arikunto, Suhardjono, dan Supardi. 2015. Penelitian Pendidikan Kelas. Jakarta: Bumi Aksara.

Alamul Huda. (2007). Panduan Praktis Microsoft Powerpoint 2007. Surabaya: Penerbitlndah.

Ashar Arsyad. (2002). Media Pembelajaran. Jakarta : PT. Raja Grafindo Persada

Daryanto. (2010) . Media Pembelajaran Peranannya sangat penting dalam Mencapai Tujuan Pembelajaran. Yogyakarta: Gava Media.

Majid. (2004). Pembelajaran Tematik terpadu. Bandung: Remaja Rosda Karya.

Oemar Hamalik. (2001). Kurikulum dan Pembelajaran. Jakarta: Bumi Aksara.

Riski Ilham (2004). Belajar Sendiri Langsung Praktek Microsoft Powerpoint 2002.Surabaya: Indah.

Triyanto. 2010. Mengembangkan Model Pembelajaran Tematik. Jakarta: Prestasi Pustaka. 